\title{
This time is different: An example of a giant, wildly speculative, and successful investment mania
}

\author{
Andrew Odlyzko \\ School of Mathematics \\ University of Minnesota \\ Minneapolis, MN 55455, USA \\ odlyzko@umn.edu \\ http://www.dtc.umn.edu/ odlyzko \\ Revised version, June 21, 2010
}

\begin{abstract}
The collapse of an investment mania usually reminds people that the phrase "This time is different" is dangerous. Recollections of this mantra then typically either state outright or at least imply that "It is never different." However, there is at least one counterexample to this cautious view, a giant and wildly speculative investment episode that was profitable for investors. The British railway mania of the 1830s involved real capital investment comparable, as a fraction of GDP, to about $\$ 2$ trillion for the U.S. today. It faced withering skepticism and criticism, much of it very reasonable, as its supposedly rosy prospects were based on extrapolation from the brief experience of just a couple of successful early railways. Yet by the mid-1840s, it was seen as a great investment success.

The example of the railway mania of the 1830s serves as a useful antidote to claims that bubbles are easy to detect or that all large and quick jumps in asset valuations are irrational. This episode also suggests the need to reexamine much of the work on business cycles and diffusion of technologies. The standard literature in this area, starting from Juglar, and continuing through Schumpeter to more recent authors, almost uniformly ignores or misrepresents the large investment mania of the 1830s, whose nature does not fit the stereotypical pattern.
\end{abstract}

\section{Introduction}

The literature on investment manias, meaning episodes of intense investor excitement, is dominated by cases that lead to collapses. As an example, the 1989 edition of Kindleberger's Manias, Panics, and Crashes [18] explicitly declared (pp. 3-4):

We are not interested in the business cycle as such, the rhythm of economic expansion and contraction, but only in the financial crisis that is the culmination of a period of expansion and leads to a downturn. If there be business cycles without financial crises, they lie outside our interest. Isolated financial crises that prove so manageable as to have no effects on the economic system will also be neglected. The financial 
crises we shall consider here are major both in size and in effect and, as a rule, international in scope.

The popular perception is that this is the inevitable result of all rapid asset price rises. For example, in 2009 the economist and political columnist Paul Krugman claimed that "bubbles always burst sooner or later," [19].

Neither a mania nor a bubble has a precise definition. In this paper, a mania is taken to denote an episode of intense investor excitement, accompanied by a flow of money and price rises. A bubble, in the popular sense that arises in the Krugman quote, usually denotes a rapid rise in valuations of some assets, which is implicitly or explicitly assumed to be followed by a collapse. For economists, a bubble is a rise in asset valuations that is not justified by fundamentals. In the early 19th century, a bubble meant a company created primarily to swindle investors (as in the South Sea Bubble, as the South Sea Company was perceived to be in that category). The topic of this paper, the British railway mania of the 1830s, involved a rapid rise in prices and substantial flows of investment funds, so certainly qualifies as a mania. It was followed by a price collapse, so in the popular sense it was a bubble. However, the flow of investment money continued, prices recovered, and investors got to enjoy above-market returns. Thus this mania was not a bubble in the economics sense, as it was justified by fundamentals.

By any standard other than that of the larger and more famous Railway Mania of the 1840s, the one of the 1830s was giant. At the peak of the financially exuberant early phase, British investors undertook to plow over $8 \%$ of their country's GDP into the new infrastructure, equivalent to over $\$ 1$ trillion for the U.S. today. (By way of comparison, estimates of rebuilding the U.S telecommunications infrastructure with fiber range between $\$ 150$ and $\$ 300$ billion. The wasteful and wasted spending on U.S. long-haul fiber networks during the Internet mania amounted to only about $\$ 100$ billion.) By the time they were done, half a dozen years later, cost overruns had led British capitalists to invest twice that much, equivalent to about $\$ 2$ trillion for the U.S. today. But within a few years they were happy, as they were earning above-market returns. In the fall of 1845, just as the excitement of the big Railway Mania was reaching its peak, The Times (of London) was railing against what it saw as a mad and dangerous new folly. However, an observer had a rejoinder, based on the experience of the mania of the preceding decade, which had faced similar opposition:

Of the 27 old companies some have succeeded to the extent of more than 150 per cent. advance on their original value; others 100, 80, 50, 30 per cent.; and all, so far as I know, are paying a fair percentage, or in the immediate prospect of doing so, on the capital invested. These, therefore, are not speculations, but triumphant successes; and the absorption of so much capital in them is no more to be regretted than the outlay in the dwelling-houses of London, which brings in its return in rent. ${ }^{1}$

This paper provides a brief sketch of those investment successes of the 1830s. Calling them "triumphant" is a bit of an exaggeration, as returns were not munificent, and were a pale shadow of what promoters had been promising at the start. But they were satisfactory for investors. 
The railway mania of the 1830s shows an investment pattern very different than the one that is implicitly or explicitly presented in most discussions on manias. After the speculative excitement died down, there was a period of about half a dozen years during which investors kept pumping money into railway construction. This was done in the face of adverse, occasionally very adverse, monetary conditions, wide public skepticism, and a market that was consistently telling them through the years that they were wrong. Practically none of this is reflected in the literature on business cycles and technological revolutions.

Just how significant is the singular experience of the railway mania of the 1830s? It is certainly possible to argue that it is "the exception that proves the rule." It is even easier to argue that this mania is outside the scope of many of the sources cited in Section 5 as deficient in their treatment of this episode. One could argue that the infrastructure construction funded by equity is radically different from the much more frequent, far more dramatic and attention-grabbing financial crises that are associated with large accumulations of debt, typically for consumption.

On the other hand, one can also argue that the railway mania of the 1830s should be studied precisely for the reasons listed above. Its culmination did not lead to a downturn and crisis. Instead, it resulted in the creation of a productive transportation system that had a deep and positive effect on the economy. It also occurred during the formative period of corporate capitalism, and its influence on the shaping of the legal, social, and institutional framework of modern society has been little explored.

All such considerations are omitted from this paper, although they are considered to some extent in the manuscript [28] and will be dealt with in more detail in the book of which that manuscript is a partial draft. All that is shown here, in a brief form, using widely known and accepted scholarly sources, is that the British railway mania of the 1830s was a financial success, and is either missing entirely from most standard works, or is misrepresented there.

The next section presents the basic quantitative information about the railway mania of the 1830s. Section 3 discusses briefly the size of this bubble, as compared to other ones, and also the question of what it was that motivated investors to keep pouring money into their ventures. Section 4 surveys the qualitative and quantitative arguments of the opponents and skeptics of this mania. Section 5 presents a brief sample of well-known works and how they treat this historical episode.

\section{The British railway mania of the $1830 \mathrm{~s}$}

The core of this section is composed of the figures, which display the timing and scale of this episode of rational exuberance. The sources for the key data are widely respected publications, primarily [14,21,26]. The basic reference work [26] in turn relies on the extensive scholarship of many authors. The precise sources of the various items will not be delved into here, in the interests of brevity. There are uncertainties about many of the measures of the British economy in the early 19th century. In particular, the estimates of total fixed capital investment (Fig. 4) are just educated guesses. However, the uncertainties about railway statistics are small enough so as not to affect the conclusions of this paper. 
Many of the relevant quantitative measures of the British economy as a whole, and of the British railway industry, are conveniently collected (principally from $[14,21,26]$ ) in tables 1 and 2 of [28]. That manuscript also has graphs that extend figures 3 and 4 of this work to cover the period 1830 through 1850, thus including the runup to the railway mania of the 1830s, as well as the rise and collapse of the Railway Mania of the 1840s. Figures 6 and 7 of this paper are based on original research, described below, but are not essential for the arguments of this paper. Thus all the critical data comes from widely accepted sources that have been available for a long time.

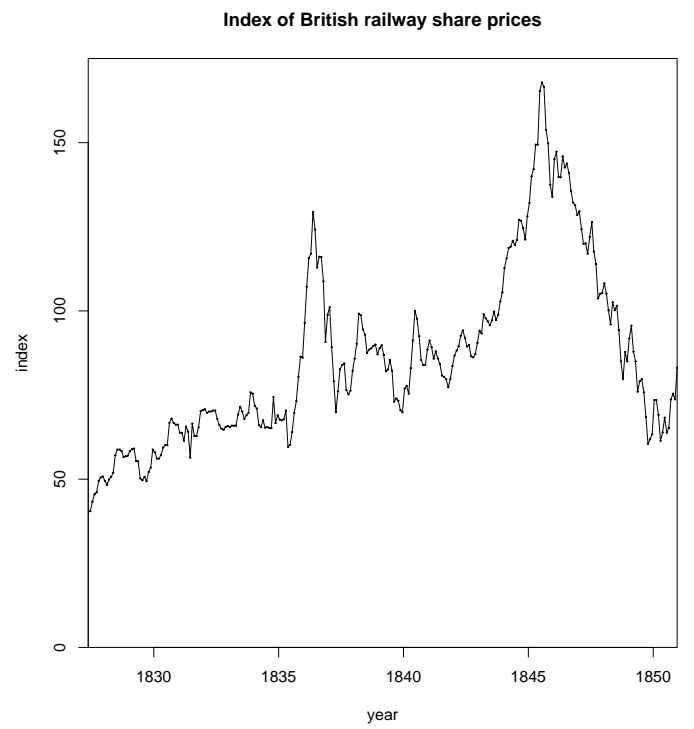

Fig. 1. Railway share prices in Britain, May 1827 through end of 1851.

Fig. 1 presents the Gayer-Rostow-Schwartz [14] index of British railway share prices. The big spike on the right represents the great Railway Mania of the 1840s. It drew in as investors Charles Darwin, John Stuart Mill, and the Brontë sisters, among others, and ended in great disappointment. In 1855, the Economist wrote that "[m]echanically or scientifically, the railways, with all their multiplied conveniences and contrivances, are an honour to our age and country: commercially, they are great failures." 2 The investment debacle of the Railway Mania of the 1840s arose to a substantial extent because the earlier railway mania of the 1830s was perceived as a success. The goal of this paper is to establish that there were solid grounds for investors in 1845, say, to think of the exuberance of the 1830s as justified.

Fig. 2 is based on the same data as Fig. 1, and presents in more detail the period 1833 through 1844. The spike on the left side of the graph reflects the excitement in 1835 and 1836. (This exuberant episode was part of a more general investment mania. The nonrailway components of that mania, with corporate, or joint-stock, banks, most prominent among them, came to the usual dismal end.) The dramatic rise in the index towards the end 
of this period corresponds to the early phases of the Railway Mania, and will be discussed in more detail at the end of this section.

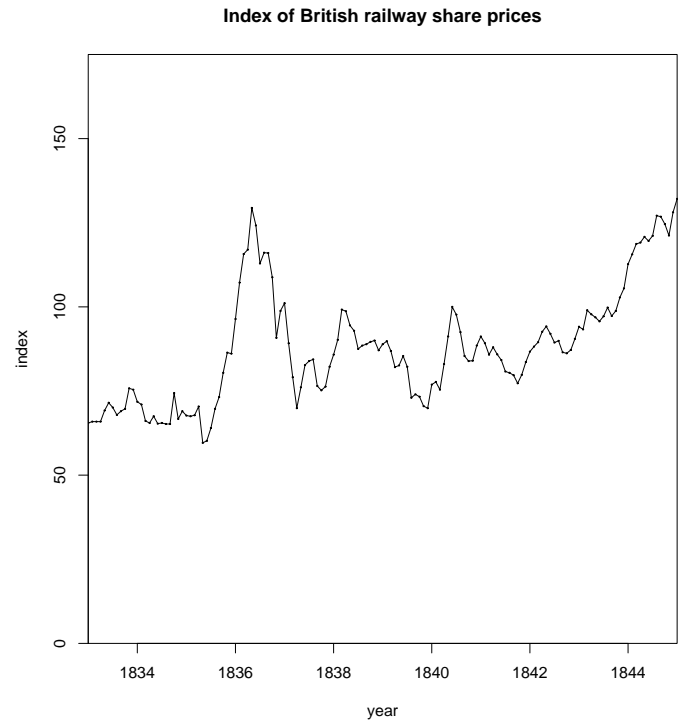

Fig. 2. Railway share prices in Britain, 1833 through end of 1844.

If we ignore the fact that the rise in the index represented in Fig. 2 in 1844 was due to increased share prices of companies started during the $1830 \mathrm{~s}$, this figure by itself is consistent with the popular view of bubbles, as reflected in the title of [6], "Boom, Bust. Repeat." Investors get excited, plow lots of money into some venture, watch prices crash, and go away to nurse their wounds. Then, a decade or so later, after the painful memories fade, they come back for another fleecing. This view is reinforced by Fig. 3, which shows miles of new railways authorized by the British Parliament ${ }^{3}$. Since promoters relied on the right of eminent domain for almost all railway projects, they needed to get permission from the government. This required substantial preparation, effort, and expense, all of which were easiest to obtain during a boom.

However, figures 2 and 3 are also deeply misleading. If we consider actual capital expenditures, a different picture emerges, shown in Fig. $4^{4}$. The money needed for the preliminary steps of doing surveys, going to Parliament, etc., was relatively small when compared to the cost of constructing railways. Investors did not just buy shares when a company was organized and put them away. They became subscribers, liable for calls up to the full amount of their shares. Thus somebody involved in a railway project that had nominal $£ 50$ shares might initially put down $£ 2$ per share as a deposit. This would pay for the preliminary expenses of the venture. If approval was obtained from Parliament, and construction started, that investor (or any one else purchasing those shares in the market later) would receive calls every few months for $£ 3$ or $£ 5$, up to the limit of $£ 50$ per share. (That is how venture capital or private equity investments function today. Investors, such as pension funds and 


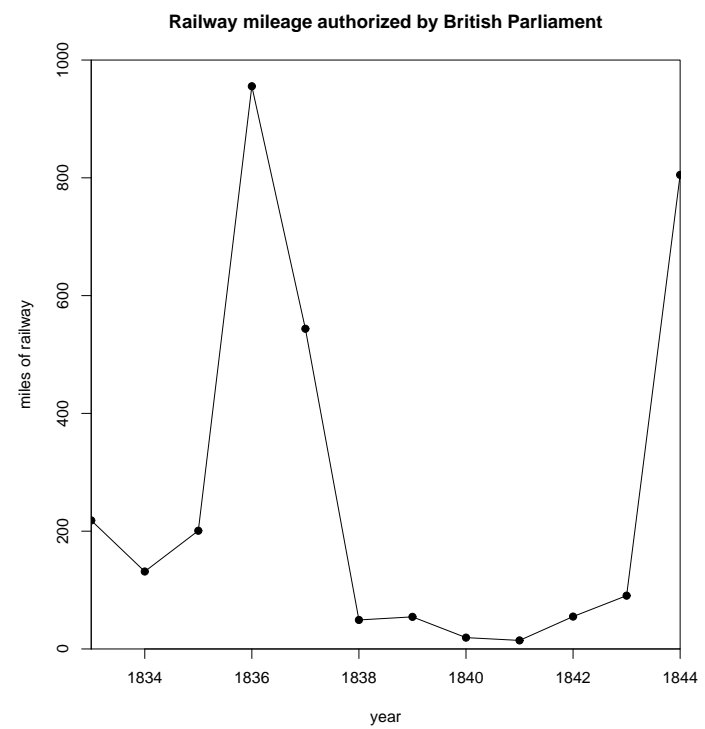

Fig. 3. Railways authorized in the United Kingdom from 1833 through 1844.

university endowments, do not send in all their money at once. Instead, they respond to calls when fund managers find appropriate opportunities to deploy the money.)

Fig. 4 shows that the heaviest investments (which were about three-quarters equity, one-quarter debt, although primarily equity in the initial years) took place in 1838 and 1839 , and amounted to about $2 \%$ of GDP each year, comparable to $\$ 300$ billion per year for the U.S. today. By comparison, the Obama administration's 2009 economic stimulus package of $\$ 787$ billion, spread over two years, amounts to a bit under $3 \%$ of GDP each year. (If we use government spending as a standard of comparison, then railway investments in the late 1830s were far larger than the stimulus package.) Further, the period 1837-43 of heavy railway investment, at least $1 \%$ of GDP each year, was dominated by depressions, financial panics, and high interest rates. Fig. 5 shows short term interest rates. The spike in 1839 corresponds to the famous crisis in which the Bank of England (which was a private bank, although with special privileges) came close to shutting its doors, and had to get an emergency loan from the Bank of France ${ }^{5}$. There had been a smaller financial crisis in late 1836 into 1837, associated with the panic of 1837 in the United States. The low total fixed investments in 1841-44 were caused by a deep depression. This depression did not have too much of an effect on railway investments, which tailed off primarily because the lines projected in the 1830s were reaching completion.

Fig. 4 shows aggregate railway investments resulting from the railway mania of the 1830s. An enlightening example of how this process looked for individual equity investors is presented in Fig. 6. The London and South Western Railway (LSWR) started out as the London and Southampton Railway, and received its Act from Parliament in 1834. Its basic shares were of $£ 50$ each, with an initial deposit of $£ 2$. As construction proceeded, there were cost overruns that had to be covered, as well as the additional expense of a branch line. These were covered by issuance of new shares, as well as borrowings. New shares were 


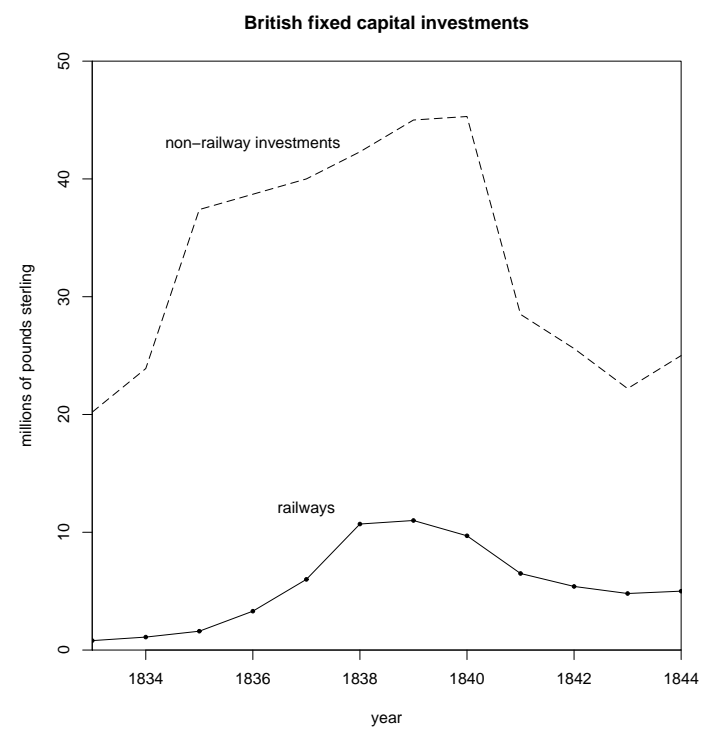

Fig. 4. Railway and other fixed capital investment in the United Kingdom from 1833 through 1844.

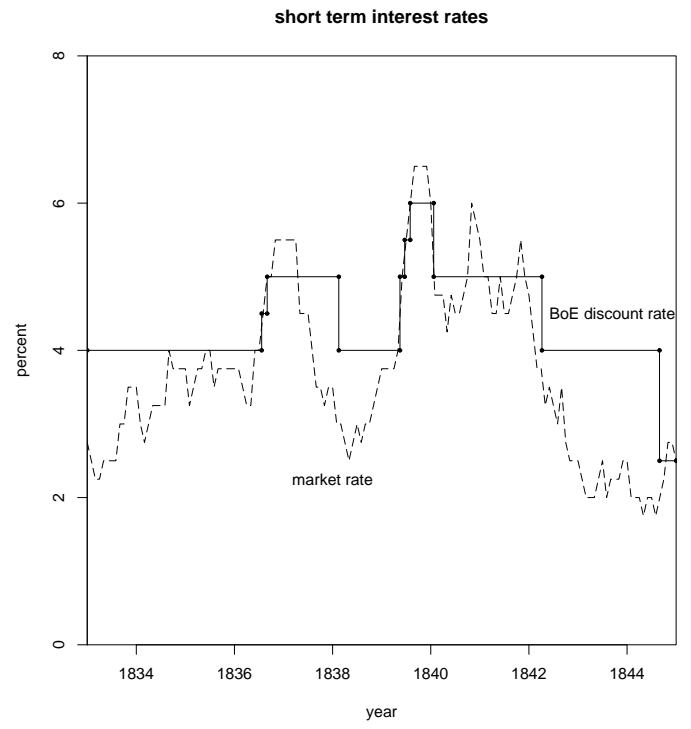

Fig. 5. Open market interest rate and the Bank of England discount rate, 1833 through end of 1844 . 
offered to existing shareholders on a pro rata basis. Fig. 6 shows the hypothetical financial outcome of the owner of a single original share who took the proportional fraction of all new share offerings, and paid all required calls ${ }^{6}$. At the end of 1843 , that person would have owned 2.31 shares, valued by the stock market at £172 (and £200 in mid-1844), and would have invested $£ 95.5$ over the years, as opposed to the initial expectation of $£ 50$. The dividend for the second half of 1844 was $£ 2$ per share, so this person would have received $£ 4.62$, for an annual rate of $9.68 \%$ on the investment ${ }^{7}$. This was regarded as exceptionally lucrative in an era when the risk-free rate on long-term government obligations was about $3 \%$. But at the start of the period represented by Fig. 6, in June 1835, such investor would have paid $£ 10$, and seen the market value it at $£ 5.5$. In fact, over most of the next two and a half years, the market was telling this investor that the LSWR venture was a mistake, as prices were mostly below the paid-up values.

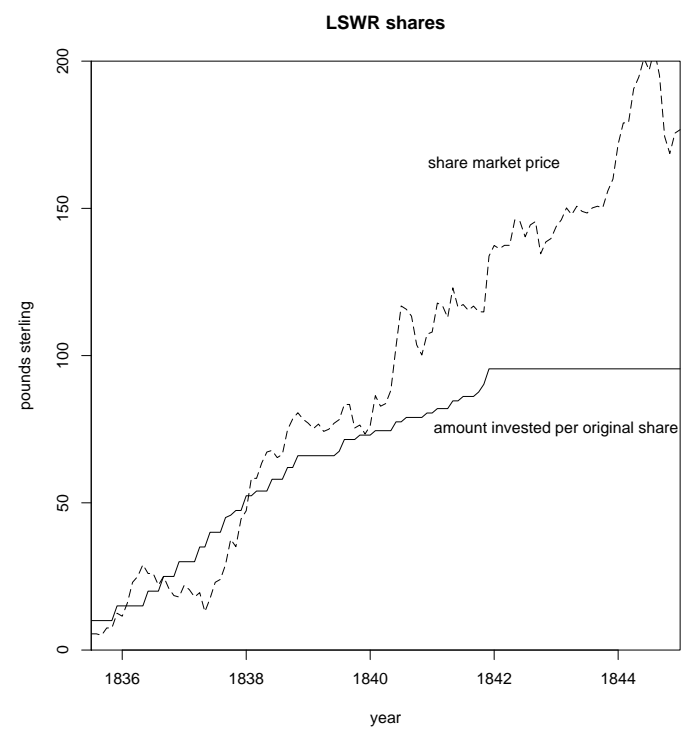

Fig. 6. London and South Western Railway (LSWR) share price and shareholder investment, June 1835 through December 1844.

Fig. 7 shows the dividend rate on an original share of the LWSR. It is not adjusted for the additional shares an investor might have acquired, and the $8 \%$ rate for the second half of 1844 indicates that a single $£ 50$ share received a dividend of $£ 2$ for those 6 months.

The financial history of the LWSR is just an illustrative example, and is not a central part of the thesis of this paper. The LWSR worked out better for its shareholders than most lines of the 1830s (although not as well as some). Still, the increasing profitability of LWSR visible in Fig. 7 was experienced by many other lines.

What were the market yields that railway shares might be expected to match? At the very end of 1844, British government long-term bonds were yielding 3\%. Dividends on Bank of England shares were $7 \%$ on the nominal value of $£ 100$ shares, but those shares were selling for about $£ 210$ each, so the market yield on these shares was about $3.3 \%$. 


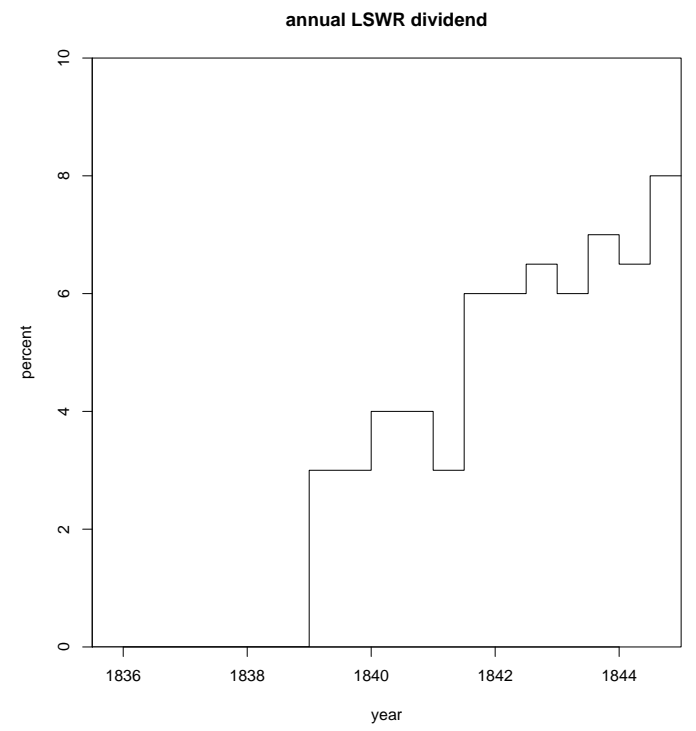

Fig. 7. London and South Western Railway (LSWR) dividend rate, June 1835 through December 1844.

East India Company shares were paying $10.5 \%$ dividends on the nominal value of their shares, and the market yield was about 3.6\%. On slightly riskier equity, $4 \%$ was about the minimum acceptable rate of return ${ }^{8}$.

Campbell [4] shows that dividends of 52 established railways (all from the 1830s, whose main lines were complete by 1843) reached $4.3 \%$ on invested ("paid-up") capital in early 1843, and then "increased steadily, reaching a peak of 7.3 per cent in July 1847." A dividend rate of $4.3 \%$ was, by the standards listed above, satisfactory, although not outstanding, barely justifying the investment. On the other hand, $7 \%$ yield was regarded as excellent.

There are some other measures of the profitability of British railways on the eve of the Railway Mania. In 1850, Lardner, p. 264 of [20], estimated that the return on total capital employed on British railways was 3.9\% in 1844, and $4.3 \%$ in 1845. Arnold and McCartney [1] using modern (and conservative) measures, computed the rates of return for a large collection of railways (representing about $71 \%$ of total capital of the British rail industry). They found (Table 1 of [1]) that the average rate of return on total equity was $4.44 \%$ in 1843 and $5.07 \%$ in 1844. (Their measure fell to $4.67 \%$ in 1845 , and lower thereafter, as the unproductive capital being invested in new lines swelled. This is not inconsistent with Campbell's finding that dividends grew until mid-1847, since in the accounting of the period, branches and extensions of existing railways were handled through separate accounts, whereas Arnold and McCartney considered total capital invested in the railway industry. To evaluate the economic success of the lines from the 1830s, we should disregard those separate accounts representing investments of the Railway Mania of the 1840s.)

The rapid rise in the railway share index visible in 1844 in Fig. 2 represents a combination of several factors. One was the increasing profitability discussed in the paragraph above. Another was the drop in interest rates, visible in Fig. $5^{9}$. Finally, there was antic- 
ipation of profits that additional railway investments would bring ${ }^{10}$. These factors, plus the bias among investors in a bull market towards looking at the positive side, did lead to the verdict of the share market in 1845 that that the railways initiated during the boom of the 1830s were indeed "triumphant successes." A more sober look, considering just the state of the industry in 1845, shows that railways were financial successes, although not triumphant ones, especially when compared with promoter promises in the 1830 s of 10 $15 \%$ dividends, and the long time that shareholders had to wait to enjoy those returns. But it is easy to excuse contemporary investors for being in an exuberant mood, especially when one considers where they had been a few years earlier.

The fate of an investor in the LSWR, who saw market values frequently lagging investments, was common. In fact, it was more common than for the LSWR, which was started earlier than most, went into service along its full length in May 1840, while many other lines were still under construction, and was considerably more profitable than most railways. In January 1840, the aggregate equity investments in a particular large collection of the principal British lines were $£ 23.3$ million and were valued by the stock market at $£ 25.0$ million. That at least shows some net gain for investors. However, most of these lines were showing prices below paid-up values. If we exclude the Liverpool and Manchester, the Grand Junction, and the London and Birmingham, the three large lines that had been in service for a while, and were serving the choicest routes, we find in this collection aggregate investments of $£ 18.0$ million being valued at $£ 14.9$ million, for a $20 \% \operatorname{loss}^{11}$. Many lines showed far greater depreciation. As an example, one of the more extreme ones, a share of the Bristol and Exeter Railway, on which $£ 40$ had been paid, was valued at that time at $£ 15$. In some cases, shares were sold at negative prices, in that the seller paid the buyer, in order to avoid the liability for future calls. Those who bought railway shares during such

periods could look at them in 1845, at the start of the Railway Mania of the 1840s, as true "triumphant successes."

\section{The size of the railway mania and investor motivations}

Fig. 4 shows that British investors persisted in pouring money into railways through thick and thin, mostly thin, over more than half a dozen years. But the incremental decisions to invest more were not always undertaken willingly. Had shareholders been presented with the question of whether to put more money into their ventures, without any prior commitments, the course of the late 1830s and early 1840s would likely have been different. However, these shareholders were not faced with an abstract investment decision. First of all, they had large sunk investments behind them, and so were naturally inclined to take an optimistic view of future prospects. Even more important, they were subscribers, obliged to respond to calls up to the full amount of their shares. Non-payment could lead to lawsuits by management or forfeiture of shares. On the other hand, this obligation was not absolute. If enough shareholders were opposed to further investments, projects could be abandoned. For example, during the Railway Mania of the 1840s, about half of the mileage authorized by Parliament was not built. During the mania that started in the mid-1830s, though, almost all projects were carried to completion. There was enough faith in the projects, and enough manipulation by interested parties, for votes to turn out in favor of 
continuation $^{12}$. This occurred in spite of adverse circumstances in the economy in general, as well as almost universal cost overruns, and widespread perception that promoters and engineers had intentionally presented overly rosy prospects. Thus although most of the investments were made some years after the speculative excitement of 1835-36 had died out, those frenzy years did play a major role in getting railway construction going. These issues are worth exploring in more depth in order to understand the role of investment manias in economic and technological progress. Somewhat more detail of the course and setting of the railway mania of the 1830s is presented in [28].

Just how big was the railway mania of the 1830s, and how does it compare to others? That is a difficult question to answer for most manias, especially since most of the activity in them is usually just a transfer of money from one group to another. The South Sea Bubble, for example, involved astronomical notional amounts, but practically no real investments. Much money changed hands, but there were no big fleets of ships built for the South Sea trade, no docks, no manufacturing facilities. The British investment mania of the mid1820s, described briefly, with references, in [28], was regarded in the early 19th century as comparable in size and degree of folly to the South Sea Bubble. According to one accounting by a contemporary observer (summarized in Chapter 5 of [28]), companies established in the mid-1820s had nominal capital of $£ 370$ million. However, in the end total investments came to only $£ 18$ million (on top of $£ 25$ million that was loaned to foreign governments during that episode of irrational exuberance). Another accounting, by the Economist at the peak of the Railway Mania in 1845, using different measures, came up with the following comparison of the the manias of that period ${ }^{13}$ :

Table 1. Comparison of British investment manias of the first half of the 19th century.

\begin{tabular}{lcc} 
mania & nominal capital & deposits \\
\hline $1824-25$ & $£ 205$ million & $£ 35$ million \\
$1834-37$ & 150 & 23 \\
$1844-45$ & 692 & 78
\end{tabular}

For comparison, British GDP in that period was around $£ 500$ million per year. In the end, actual railway investments for projects started in the 1830 s (including a few that predate the mania peak of $1835-36$ ) came to about $£ 70$ million by the end of 1843 . Thus they dwarfed all other real investments resulting from the manias of the mid-1820s and 1830s. Some more comparisons:

- Total British investments in the U.S. during the 1830s have been estimated at about $£ 35$ million ([16], p. 85).

- In 1842, an analysis of equity markets in the UK showed total nominal capitalization of $£ 224$ million, with $£ 57$ million coming from railways ([34], p. 157).

Hence by any reasonable standard, the real capital investments of this railway mania were indeed huge even when compared to the size of the economy, and far larger than from most other manias. (Those of the Railway Mania were about twice as large, see Table 2 in [28]. 
Those of the railway mania of the 1860s were almost as large as those of the Mania of the 1840s, but were spread over a longer period, and took place in an economy almost twice as large.)

\section{The British railway mania of the 1830 s and its skeptics}

The British railway mania of the 1830s had armies of organized opponents and even larger hordes of skeptics ranged against it. Much of the activity came from economic interests, especially canals and turnpikes, that were threatened by the new technology. But there were many other sources of opposition, such as aristocrats trying to protect their favorite fox hunting grounds and educational institutions (Cambridge, Eton, and Oxford prominent among them) concerned about moral corruption of their students. These activities have been covered extensively in the literature, starting with the early histories of British railways by Francis [12] and Williams [38] in the early 1850s. What this coverage largely misses, though, is the solid foundations for much of the criticism of railway expansion plans. For a more careful consideration of this issue, see [28], especially Chapter 8 there. In particular, aside from the potential impact on competitors and society at large, there was the central issue of whether railways would be profitable. There were serious doubts about the projected construction budgets. There were also substantial questions about estimates of demand, as those were made using a systematic but untested methodology. The locomotive-powered railway was developed for slow transport of heavy coal wagons over short distances. To the great surprise of most railway enthusiasts, demand for fast passenger transport materialized suddenly, and provided most of the revenues. But that had been initially demonstrated only on a single large 30-mile line. The experience of that line was then extrapolated to other localities, and long trunk lines. It succeeded, but only through a fundamental misunderstanding. Promoters and investors had expected most of the demand to be for travel between terminal cities of the trunk lines, whereas actual demand turned out to largely involve intermediate stations, a fact that did not become widely known until the late 1840s. (See [28] for more details.) Thus investment in railway involved not just risk, but huge uncertainty.

Two eminent and prominent economists of that era, John Ramsay McCulloch and John Stuart Mill, were both enthusiastic about the utility of railways for society. However, both were skeptical about investors being able to make money from them. Mill declared in 1836 [25] that "on the face of the matter it seems absurd to suppose that both the Great Western Railway, and the London and Southampton, can pay; though it is just possible that either of them might, if the other did not exist." (Both lines were paying very well by the end of 1843.) In early 1837, McCulloch wrote:

There was, in fact, for some time, quite a mania in favour of [railways]; many of which were, in consequence, entered into without due consideration; and it is not, perhaps, very likely, unless some discovery be speedily made by which the cost of their construction may be materially lessened, that half the projects of this sort now on foot, supposing they were realised, will afford a remunerating dividend, at least for some considerable period. Some of the best lines, such as that from London 
to Birmingham and thence to Manchester, and from London to Brighton, London to Bristol, \&c., may, no doubt, be expected to yield an ample return. We incline, however, to think that the expectations entertained with respect to the immediate productiveness even of those lines are too sanguine. ${ }^{14}$

Just like Mill, McCulloch turned out to be almost completely wrong. Almost all the projects were built, contrary to the doubt he implied in writing "supposing they were realised." Almost all of those were also able to "afford a remunerating dividend" by 1843. Further, not only was no "discovery ... speedily made" for lowering costs of construction, but the skeptics' fears turned out to be extremely well justified. Final costs on most lines came to about twice the original estimates. However, demand estimates turned out, from the perspective of 1845 , say, to be amazingly accurate, more accurate than most estimates that are made today for large transport projects. This is detailed in [28]. The methodology was based on several false assumption that canceled each other out to produce good results. The cost overruns meant that realized profits were far smaller than initial estimates. Fortunately those estimates had been so generous that the final outcome was very satisfactory for investors, especially when compared to all other investments made during the manias of the 1820 s and 1830 s.

The skepticism of both McCulloch and Mill was reasonable, it's just that it turned out to be incorrect. It is hard to predict accurately how society, technology, and economics will interact. There were many other highly touted technologies in the 1830s that disappointed their promoters and investors. As one example, in the early 1830s, before the railway mania of that decade, McCulloch was skeptical about both railways and steam carriages (in the original 1832 edition of [24]), and so he turned out to be right on one and wrong on the other. Steam ships, one of the major advances of that era, disappointed many of their promoters, too.

The main point of this section is to demonstrate that the railway mania of the 1830s was an extremely speculative one. Investors relied on an untested technology and an untested demand estimation methodology. Yet they succeeded! That success played a key role in launching the great (and disastrous for shareholders) Railway Mania of the 1840s. As the excitement of that bubble was building in early 1845, the Economist wrote:

The origin of the very favourable reception with which railways have met at this time, is no doubt to be traced to the fact that, of all the schemes which originated in the speculative period of 1835-36, they were the only ones which stood the test of the succeeding pressure, without any disastrous losses. ${ }^{15}$

\section{The British railway mania of the 1830s in the literature}

This section documents the neglect or misrepresentation of the British railway mania of the 1830s in the literature. Only a small selection of books is covered, although they are selected from among the more prominent ones. No attempt is made to discuss the extent to which this affects the main messages of these books. To do the latter would require a book by itself. For example, Lewin's books on early British railways [21,22] are indispensable 
tools for any scholar researching that period. They contain a detailed chronology and useful statistics. Further, coming from an experienced railroad manager, these books explain well the logic of particular railway links in terms of accommodating various types of traffic flows. But they say very little about the financial environment of the time. Lewin did not attempt to cover railway economics, so it is hard to criticize him for the omission. But it is possible to argue that a much deeper understanding of the events chronicled in those books would be obtained if this deficiency were remedied. However, that would require a long discussion. So let us leave that aside, and go on a whirlwind tour of various widely known books.

There are three features of the railway mania of the 1830s that are important, and various books will be rated on the extent to which they cover them:

- A. It arose in a burst of general speculative excitement, but faced extensive skepticism, much of it well grounded.

- B. Investors had to keep providing funding over an extended period, in adverse economic conditions.

- C. Railways built during this period were viewed as "triumphant successes" in the end.

All three points must have been known to many experts in the area at least in principle. However, I have found only one book, British Transport by Dyos and Aldcrof [9], which covers all of them well, although it does so extremely briefly. I am not aware of a single source that does full justice to A. Hence even a slight mention of those circumstances will be regarded as satisfactory.

The 2005 edition of Kindleberger's classic Manias, Panics, and Crashes (this one prepared in collaboration with Aliber) [18] has nothing substantive to say about railroads. Its listing of "The big ten financial bubbles" (p. 5) starts with the Dutch Tulip Bulb Bubble, which has had a huge impact on popular imagination, but essentially no discernible effect on the real economy. None of the three big British railway manias of the 19th century make it into this list of "big ten." There is a brief acknowledgment (in the table on p. 260) that railways were somehow involved in the British financial crisis of 1847 , but that is all. Thus this book fails on all three points, A, B, and C.

Reinhart and Rogoff's This Time is Different similarly has nothing on any of A, B, or C. (Like Kindleberger, this volume is devoted to spectacular events, such as when a banking system has a seizure, or a government defaults on its obligations, and to the buildup of debt that usually precedes the seizure.) The table on p. 387 there has a listing of a UK crisis from March 1837 to 1839, with a reference to the book of Conant, A History of Modern Banks of Issue [8]. Conant, though, discusses only the monetary situation of the time, and only briefly alludes to railway speculations that were prominent in early 1836 ([8], p. 629). Reinhart and Rogoff conclude their Preface ([32], p. xxxv) with the comment:

We hope that the weight of evidence in this book will give future policy makers and investors a bit more pause before next they declare, "This time is different." It almost never is.

Unlike the other sources cited earlier, they astutely inserted the qualifier "almost," although they did not present any counterexamples that call for it. This paper fill that gap. 
Among modern books on long waves of investment and technological innovation, As Time Goes By of Freeman and Louçã [13] talks of "two waves of investment in 1834-7 and 1844-7" (p. 190). This fits neither the pattern of Parliamentary authorizations nor actual real capital investments, and has no detailed discussion. Thus one can say that $\mathrm{A}, \mathrm{B}$, and $\mathrm{C}$ are all lacking.

Technological Revolutions and Financial Capital by Perez [29] does not have a clear chronology of the railway age. It does nominate the period 1848-50 as a "turning point" in the "installation and deployment" dating of the phases of what it calls the "2nd Great Surge", the "Age of Steam and Railways" (p. 57). But it does not explain why this time slot (coinciding the with collapse of the Railway Mania) is a better candidate than the railway manias of the 1830 s and 1860 s, and how the presence of three instances of extreme investor exuberance about the same technology affects the main thesis of the book.

Nairn's Engines That Move Markets [27] discusses the railway manias of the mid-1820s, mid-1830s, and the mid-1840s, and shows graphs of share prices and Parliamentary authorizations during those periods. However, there is neither a sense of how speculative the investments were, nor of the long stretch over which capital was being raised for the lines started in the 1830s, nor that they turned out in the end to be seen as "triumphant successes." So we can say that A is covered partially, but neither B nor C is.

Chancellor's Devil Take the Hindmost [5] does mention the "railway fevers" of the mid-1820s and mid-1830s. However, the discussion of the latter (as in the statement that "[w] hen the boom progressed to bust in 1837, the crisis extended to the railways," [5], p. 125) suggests that railway investment stopped at that point. So we can say that points B and $\mathrm{C}$ are missing.

The investment manager Jeremy Grantham carried out a study of 28 large investment manias that spanned several centuries. He claimed that "[e]very one of the 28 went back to trend, no exceptions, no new eras, not a single one that we can find in history" [37]. His procedure (looking for excursions of at least two standard deviations from the mean in prices) does show the railway mania of the 1830s following that pattern, as indeed railway share prices did return to trend by early 1840s in Fig. 2. But this is a matter of methodology, and his methodology ignores all the spending that took place after the crash of 1837.

Among more general history books, the first volume of Clapham's Economic History of Modern Britain [7] does discuss the speculative excitement of the railway mania of the mid-1830s, and so covers A, at least to some extent ${ }^{16}$. However, in the treatment of the late 1830s and early 1840s, Clapham's book mentions low share prices, but not the heavy calls. And it does not make it clear that by the mid-1840s, those railways started in the 1830s were nicely profitable. So one can say that [7] covers A, but misses both B and C.

Among general books on transport history, Bagwell's The Transport Revolution [3] covers A slightly, B rather well, but misses out on C. British Transport by Dyos and Aldcrof [9] was already mentioned as providing good, although brief, coverage of all three. Ransom's The Victorian Railway and How It Evolved [30] covers all three points with varying degrees of accuracy ${ }^{17}$. 
In the second half of the 20th century there were a number of deep studies of early British railways by economic historians such as C. H. Feinstein, G. R. Hawke, R. J. Irving, A. G. Kenwood, B. R. Mitchell, H. Pollins, and M. C. Reed. They are the principal sources for the data in [26] and thus indirectly for Section 2 of this paper. Apparently the first careful study to recognize and quantify the extent to which the railway mania of the 1830s stretched far beyond the limits of its speculative genesis was A Study in Trade-Cycle History by Matthews, [23]. In Chapter 8, pp. 106-113 and 120-123, Matthews did an admirable job, given that this was only a small part of his project, in estimating from scratch the actual expenditures on railway construction for each of the years 1833 through 1842 . He also gave some sense of the speculative fever of 1835-36. On the other hand, he did not deal at all with how this boom was perceived in the mid-1840s, as that period was outside the scope of his study. Thus we can say that he did well on A and B, but not on C. Of subsequent works, I will just briefly comment on Reed's Investment in Railways in Britain, 1820-1844 [31]. An extremely valuable work, it presents much material not available elsewhere. It has extensive coverage of $\mathrm{B}$, the long stretch of investments in adverse circumstances, and the financial tools that were used. It also has some coverage of $\mathrm{A}$ and $\mathrm{C}$, but those can be questioned. In particular, by stopping some of his data collection at 1843 (for example, in the table on p. 25), Reed missed the large increase in railway industry profits in 1844-45, so that his discussion on what motivated the Railway Mania on p. 268ff can easily be criticized.

Let's next consider some earlier works. Juglar was a pioneer in the study of business cycles. His attention in [17] was directed primarily at financial crises. He knew that railways were the most prominent objects of speculation in England in 1835. However, he stated that the results of the mania of 1835 were the same as those of 1825 ([17], p. 66), which was true for the non-railway elements of that mania, but false for railways. A few pages later, he had a section entitled "Fin de la crise et liquidation (1839-1840)" ([17], p. 69) which discussed the financial mopping up of the crisis of the late 1830s. It does not mention at all that railway construction was proceeding at full speed during that period. Thus this pioneer appeared to be totally unaware of the role and nature of the railway mania.

Schumpeter in his Business Cycles placed the end of the first identifiable Long (Kondratieff) Wave at 1842 primarily because of his perception of railway development in England ([33], vol. 1, p. 304). But this perception was faulty. He was aware that railways were part of the investment mania of the $1830 \mathrm{~s}$, but underestimated their role, and the nature of the investment they attracted. He wrote ([33], vol. 1, p. 278) that

... speculative excitement and its reflex in the talk of the time should not induce us to exaggerate the importance of the, roughly, thousand miles sanctioned in the boom itself and the, roughly, 490 miles that according to ... had been constructed by 1838, involving a total expenditure of 13.3 million pounds. The great development that within a few years created almost the whole skeleton of the English railway system was the work of the forties.

The timing, scale, and effect of the railway mania of the 1830s are thus all represented incorrectly, and in particular miss the fact that money pouring into railway construction was rising in 1838. This misunderstanding is confirmed by another quote from the book, 
to the effect that the Railway Mania of the 1840s was "the one full-fledged railroad boom which England experienced" ([33], vol. 1, p. 343), which ignores the booms of the 1830s and 1860s.

Juglar, Schumpeter, and other early thinkers did not have convenient collections of economic statistics, such as those of [26], at hand. Those are products of the extensive modern scholarship cited earlier. Still, it would not have been hard for Juglar or Schumpeter to get a rough sense of the extended period over which the railway mania of the 1830s unfolded (say from the data in government reports showing how many miles of railway were being opened to traffic in the early 1840 s, miles that clearly came from the concluding phases of the investment of that mania). They may have been partially misled by reading one of the basic and most respected sources for the economic history of that period, Tooke's History of Prices $[35,36]$. Tooke is one of the many fascinating personalities of that era. Born in 1774, he was a successful businessman who, starting in his 40s, became one of the most influential monetary economists of his time. He was also one of the earliest promoters of the London and Birmingham Railway, and served as a director of this company for over a dozen years. In addition, he invested in some of the new lines of the Mania. Thus if anyone might be expected to have a good understanding of the economic aspects of railway growth in England, it surely would be Tooke. Unfortunately the actual treatment in his book is disappointing. There are some interesting comments about early railways in [35], vol. 2, pp. 275-76. In vol. 3, published in 1840 and covering the years 1838-39, he mentioned (p. 278) "the very large amount of capital which is absorbed, and wholly unproductive of immediate income (whether permanently so is another question)," primarily in railways. So he was aware large investments were involved, but there is no unambiguous statement that "the very large amount" was still growing rapidly, and that the total was going to double over the next five years. And there is that doubt as to whether those funds would ever cease to be "wholly unproductive." In 1848, he published vol. 4, which covered the years 1839-47. There, in explaining the origins of the Railway Mania around 1844, he stated that one of the main motivations came from "the favourable results of the investments made in the principal lines of railway then in operation" (pp. 63-64). However, he did not say anything about his earlier skepticism having proved wrong, nor about the extended period over which those "investments made in the principal lines of railway then in operation" had been carried out. The 5th volume of the work, published in 1857, had a very extensive section on railways. This section was written by Tooke's collaborator, the well-known economic statistician William Newmarch. However, "the opinions expressed, and the tenour of the information conveyed, [had Tooke's] entire concurrence" ([36], vol. 5, Preface, p. ix). One passage there stands out for being clearly and completely incorrect (([36], vol. 5, p. 371):

In 1835 and 1836, nearly the whole catastrophe was comprised in the first great collapse. Shares bought at [£50] fell to [£5], and remained there; and the whole of the fall was so much lost to the holder. But, severe as that loss might be, it was the whole calamity that could befall him. Not so with the Railway Subscriptions of 1845. Those subscriptions entailed the obligation of meeting a long series of Calls, extending over three or four years; and, in truth, the cases were but few in which the 
necessity of meeting the calls was not a far greater misfortune than the depreciation on the first price.

Since Newmarch was born in 1820, perhaps one could excuse him for not understanding that the speculations of the mid-1830s involved an even more prolonged period of painful calls than those of the mid-1845s. (It was only the outcome that was dramatically different.) However, it is hard to understand how Tooke could have let this passage pass. He was 83 at the time this volume was published, but according to his obituary, was in possession of his full mental powers.

Another amusing example of a combination of short memories and basic innumeracy, where Tooke was directly responsible, and at a younger age to boot, occurs in [35], vol. 4, footnote on pp. 313-14. This footnote presented a table of railway capital expenditures from 1840 through the first half of 1847, based on figures cited by the Chancellor of the Exchequer in a speech in the House of Commons on Nov. 26, 1847 (reported in The Times, Nov. 27, pp. 2-3). The figures for 1840 and 1841 in that table were zero and $£ 1.47$ million, respectively, too low by $£ 9.7$ and $£ 5$ million, respectively. How could such preposterous figures get presented and be widely accepted? Well, a careful reading of the speech by the Chancellor of the Exchequer (which was full of warnings that precise estimates were impossible, and all estimates had to be treated with caution) shows that the figures he cited were only for spending resulting from Parliamentary authorizations from 1840 and later years. But almost all of the expenditures for the projects of the railway mania of the 1830s, including the cost overruns, had been approved by 1839. The Times used a leader (Nov. 27 issue, p. 4) to acclaim the speech as having refuted the claims of another politician:

The salient points of absurdity in Lord George Bentinck's statistics were so numerous that we found it impossible to notice more than a portion. It was tantalizing indeed to see so luxuriant a crop, and feel that human hands could not grasp more than a handful.

Unfortunately, while there were "points of absurdity" in Bentinck's statistics, such points were, if not equally numerous, than certainly more misleading, in the statistics of the Chancellor of the Exchequer. It is hard to understand how Tooke could accept those statistics as valid.

Tooke was not the only contemporary observer to miss some of the salient features of the railway mania of the 1830s. Walter Bagehot, the famous 19th century economist, political commentator, and editor of the Economist, declared in 1856 [2]:

A great deal has been written and is being written on panics and manias - a great deal more than with the most outstretched intellect we are able to follow or conceive; but one thing seems certain, that at particular times a great many stupid people have a great deal of stupid money. ... Every now and then, from causes which are not to the present purpose, the money of people of this class - the blind capital (as oculists call it) of the country - happens to be particularly large and craving; it seeks for some one to devour it, and there is "plethora" - it finds some one, and there is "speculation" - it is devoured, and there is "panic." 
Bagehot was born in 1826, so was a young boy during the railway mania of the 1830s. However, had he inquired of people still alive, or investigated in published sources, he would have discovered that sometimes the seemingly "stupid money" is not so stupid, or is at least lucky, and instead of being "devoured," gets multiplied.

The Gayer, Rostow, and Schwartz study [14] is adequate on A, but fails on B and C. It shows no understanding of the fact that actual capital investments trailed Parliamentary authorizations by years. For example, it claims ([14], vol. 1, p. 284) that

... the crisis of 1836 ... brought about a stagnation in new investment generally. There was some revival in 1838 and the early months of 1839, but from the financial crisis of 1839 to the return of monetary ease and general confidence in 1842 enterprise was at a fairly low level.

This is simply wrong, at least for the substantial portion of "enterprise" that involved railways. Later, in the discussion of the origins of the Railway Mania of the 1840s, there is no recognition of the role that the perception that the railways of the 1830s were "triumphant successes" played in giving rise to the Railway Mania of the 1840s.

\section{Conclusions}

The British railway mania of the 1830 s is neglected and misrepresented in the literature. It was a giant and very speculative undertaking that succeeded. That time was really different. This is something that policy makers should keep in mind in considering episodes of great investment exuberance. The implications of this historical event for investment manias and technology diffusion deserve much deeper investigation.

\section{Notes}

${ }^{1}$ The Times, Sept. 2, 1845, p. 2, anonymous letter entitled "Railway speculation."

${ }^{2}$ The Economist, September 15, 1855, pp. 1010-1011.

${ }^{3}$ Data derived from [21], p. 186.

${ }^{4}$ Data taken from [26].

${ }^{5}$ The Bank of England discount rate is taken from [11], vol. 2, pp. 275-76. The open market rate, "for first class mercantile bills," is taken from [36], vol. 6, p. 544.

The railway share index in Fig. 2 peaked in April 1836, some months before the financial conditions of that year started worsening. That is consistent with some comments from contemporary observers, who noted that speculation had turned away from railways and towards other ventures, especially banks, around that time. Thus it was not high interest rates, or a general stock market crash, that stopped railway promotion 
${ }^{6}$ Prices and paid up values for most years obtained from Herapath. This serial started out as the monthly Railway Magazine and eventually evolved into the weekly Herapath's Railway and Commercial Journal, and is commonly called just Herapath. For the years 1841-42, values were taken from the Railway Times. Adjustments were made for various new share issues, except for those of 1844, which were ignored. There were 20,000 initial shares of $£ 50$ each. In 1837, additional 16,000 shares of $£ 25$ each were created, but ones that carried the same rights to dividends as the original shares. (In other words, these were shares being sold at a 50\% discount.) Later there were 6,000 Gosport shares of 1839, and 42,000 "tenths" shares of 1841 that became 4,200 regular shares. In those last two cases shareholders were expected to pay through calls the full $£ 50$ per share.

${ }^{7}$ As usual, "your mileage may vary." Many shareholders did not have enough faith in the enterprise to pay the calls, or lacked the means to do so. Those who sold out were often heavy losers.

A person who only paid the obligatory minimum on LSWR, namely the full set of calls on an original $£ 50$ share, ended 1843 with an investment worth only about $50 \%$ more than was paid up, and a dividend yield of $8 \%$.

In all these computations, the time value of money is ignored, as it was ignored as a first approximation in early Victorian times.

${ }^{8} \mathrm{~A}$ quote from 1845 in [4] is just one example showing an expectation of a $4 \%$ yield on equity investments.

${ }^{9}$ Fig. 5 shows only short term interest rates. Long term rates did not vary much during this period, at least not by modern standards. According to [15], Table 19, pp. 195-96, the interest rate on 3\% Consols varied in the range of 2.96 to $3.56 \%$ during this period. However, the refinancing of a large part of the huge national debt in 1844, which lowered the nominal interest rate on it from 3.5 to $3 \%$ (with a transitional period at $3.25 \%$ ), had, according to all contemporary accounts, an immensely stimulating effect on common shares of all kinds, and on new railways in particular.

${ }^{10}$ At the end of 1844 , which is when Fig. 2 ends, the planned additional railway investments were relatively modest. Hence it was not unreasonable for investors to expect that existing companies would be able to profit from this expansion. See [4] for a comprehensive index of shares prices and dividends during the period 1843-50.

${ }^{11}$ Valuations obtained from the weekly railway share tables in the Jan. 25, 1840 issue of Herapath. A particular type of share (some lines had several types) was included in the calculation only if the table provided the number of shares, the nominal value of the share, the amount paid up, and a price. Thus this calculation does not cover all the capital invested in the lines listed there.

${ }^{12}$ There were a few legal technicalities that complicated the picture, but did not seem to change the outcome perceptibly. In theory, a railway Act was a contract, which gave 
the company certain rights to issue limited liability shares, acquire land whether owners wanted to sell or not, and so on, but in return obliged this company to actually construct the line. In practice, Parliament never tried to enforce these contracts, and there had been earlier railways as well as canals that had simply been abandoned. On the other hand, there was no clean way to actually close down a project that investors were not willing to push forward. It was only in the late 1840s that Parliament enacted legislation to clear up the legal messes that such situations gave rise to.

${ }^{13}$ Article "Retrospect and comparison," the Economist, Oct. 18, 1845, pp. 998-99. That piece has considerably more detail than is presented here.

$14[24]$, p. 65 of Supplement.

${ }^{15}$ The Economist, April 5, 1845, p. 310.

${ }^{16}$ One can certainly quarrel with some of Clapham's judgment. For example, he wrote of the peak of the speculative phase ([7], p. 388):

The thing had been overdone during 1836-7. ... Blind capital, seeing its 5 per cent., a totally different thing from the clear-eyed capital of the Quaker business men from the Midlands and the North, had accumulated for the raiders.

There is some justice to this quote, new types of investors did emerge to participate in the railway mania at its peak. However, by that time there was more evidence about both the technology of railways as well as about demand. Earlier in the decade, when those "Quaker business men" were so much more prominent, many critics regarded them not as "clear-eyed," but as wild-eyed lunatics, venturing huge sums on a wild-goose chase.

${ }^{17}$ Ransom covered $\mathrm{C}$ well, with the statement on p. 81 that shortly before the Railway Mania, "the trade depression had bottomed out just at the time when the first generation of main lines had been in operation long enough to demonstrate that they were both profitable and generally beneficial." But some of the coverage of points A and B is questionable. For example, his book states (p. 69) that for the Eastern Counties Railway, "great plans proved over-ambitious and only parts ... were actually built." The problem was that not with plans that were over-ambitious, but rather that they were based on exaggerated promises, and execution was marred by corruption and incompetence. Hence investors balked at funding the huge jumps in capitalization that would have been required to carry the original plans into execution.

\section{Acknowledgments}

I thank the editor and the anonymous referees for their comments and suggestiongs. This paper came from a much larger project, which will be documented mostly elsewhere. The many people and institutions who assisted in different phases of that venture are listed at 〈http://www.dtc.umn.edu/ odlyzko/doc/mania-ack.html〉. 


\section{References}

1. A. J. Arnold and S. McCartney, "Were they ever 'productive to the capitalist'? Rates of return on Britain's railways, 1830-55," J. European Economic History, vol. 33, no. 2, Fall 2004, pp. 383-410.

2. W. Bagehot, "Edward Gibbon," National Review, vol. 2, Jan. 1856, pp. 1-42.

3. P. S. Bagwell, The Transport Revolution from 1770, Barnes \& Noble Books, 1974.

4. G. Campbell, "Cross-section of a 'bubble': Stock prices and dividends during the British Railway Mania," Available at SSRN, 〈http://ssrn.com/abstract=1402642〉. Downloaded May 23, 2010.

5. E. Chancellor, Devil Take the Hindmost: A History of Financial Speculation, Farrar, Straus and Giroux, 1999.

6. E. Chancellor, "Boom, Bust. Repeat.," Wall Street Journal, Oct. 9, 2009.

7. J. H. Clapham, An Economic History of Modern Britain: The Early Railway Age, 18201850, Cambridge Univ. Press, 1926.

8. C. A. Conant, A History of Modern Banks of Issue, 5th ed., G. P. Putnam's Sons, 1915.

9. H. J. Dyos and D. H. Aldcroft, British Transport: An Economic History from the Seventeenth Century to the Twentieth, Leicester University Press, 1969.

10. C. H. Feinstein and S. Pollard, eds., Studies in Capital Formation in the United Kingdom, 1750-1920, Oxford Univ. Press, 1988.

11. J. Francis, History of the Bank of England, Its Times and Traditions, 2nd ed., 2 vols., Willoughby \& Co., 1847.

12. J. Francis, A History of the English Railway, Its Social Relations \& Revelations, 18201845, Longman, Brown, Green \& Longmans, 1851. Reprinted by David \& Charles, 1967.

13. C. Freeman and F. Louçã, As Time Goes By: From the Industrial Revolutions to the Information Revolution, Oxford Univ. Press, 2001.

14. A. D. Gayer, W. W. Rostow, and A. J. Schwartz, The Growth and Fluctuations of the British Economy, 1790-1850: An Historical, Statistical, and Theoretical Study of Britain's Economic Development, 2 vols., Oxford Univ. Press, 1953.

15. S. Homer and R. Sylla, A History of Interest Rates, 3rd ed., Rutgers Univ. Press, 1996.

16. L. H. Jenks, The Migration of British Capital to 1875, Knopf, 1927.

17. C. Juglar, Des Crises Commerciales et de leur Retour Périodique en France, en Angleterre et aux États-Unis, Guillaumin et Cie., 1862.

18. C. P. Kindleberger and R. Z. Aliber, Manias, Panics, and Crashes: A History of Financial Crises, 5th ed., Wiley, 2005. (First ed., with Kindleberger as sole author, Basic Books, 1978.)

19. P. Krugman, "Revenge of the glut," New York Times, March 2, 2009. Available at 〈http://www.nytimes.com/2009/03/02/opinion/02krugman.html〉.

20. D. Lardner, Railway Economy; A Treatise on the New Art of Transport, its Management, Prospects, and Relations, Commercial, Financial, and Social, ..., Harper \& Brothers, 1850.

21. H. G. Lewin, Early British Railways: A Short History of Their Origin 6 Development, 1801-1844, Locomotive Publishing Co., 1925. 
22. H. G. Lewin, The Railway Mania and its Aftermath, 1845-1852, Railway Gazette, London, 1936. Republished with an introduction by C. R. Clinker by David \& Charles, 1968.

23. R. C. O. Matthews, A Study in Trade-Cycle History: Economic Fluctuations in Great Britain, 1833-1842, Cambridge Univ. Press, 1954.

24. J. R. McCulloch, A Dictionary, Practical, Theoretical, and Historical, of Commerce and Commercial Navigation: Illustrated with Maps and Plans, Longman, Rees, Orme, Brown, Green, \& Longman, 1837.

25. J. S. Mill, "State of politics in 1836," London and Westminster Review, vol. 3 (or 25), April 1836, pp. 271-278. Reprinted in The Collected Works of John Stuart Mill, vol. 6, available online at $\langle$ http://oll.libertyfund.org/?option=com_staticxt\&staticfile $=$ show.php\%3Fperson $=21 \&$ Itemid $=28\rangle$.

26. B. R. Mitchell, British Historical Statistics, Cambridge Univ. Press, 1988.

27. A. Nairn, Engines That Move Markets: Technology Investing from Railroads to the Internet and Beyond, Wiley, 2002.

28. A. M. Odlyzko, "Collective hallucinations and inefficient markets: The British Railway Mania of the 1840s," January 2010 manuscript available at SSRN, $\langle$ http://ssrn.com/abstract $=1537338\rangle$.

29. C. Perez, Technological Revolutions and Financial Capital: The Dynamics of Bubbles and Golden Ages, Edward Elgar, 2002.

30. P. J. G. Ransom, The Victorian Railway and How It Evolved, Heinemann, 1990.

31. M. C. Reed, Investment in Railways in Britain, 1820-1844: A Study in the Development of the Capital Market, Oxford Univ. Press, 1975.

32. C. M. Reinhart and K. S. Rogoff, This Time is Different: Eight Centuries of Financial Folly, Princeton Univ. Press, 2009.

33. J. A. Schumpeter, Business Cycles: A Theoretical, Historical, and Statistical Analysis of the Capitalist Process, 2 vols., Porcupine Press, 1939.

34. W. F. Spackman, Statistical Tables of the Agriculture, Shipping, Colonies, Manufactures, Commerce and Population of the United Kingdom of Great Britain and its Dependencies; Brought Down to the Year 1843, Longman \& Co., 1843.

35. T. Tooke, A History of Prices, and of the State of Circulation, 4 vols., Longman, Brown, Green, Longmans, and Roberts, 1838, 1840, 1848.

36. T. Tooke and W. Newmarch, A History of Prices, and of the State of Circulation, During the Nine Years 1848-1856, 2 vols., vols. 5-6 of Tooke's The History of Prices from 1792 to the Present Time, Longman, Brown, Green, Longmans, and Roberts, 1857.

37. S. Ward, "After the Deluge: An elegant thinker deconstructs the stock market's latest bubble and its likely aftermath," Barron's, Aug. 6, 2001.

38. F. S. Williams, Our Iron Roads: Their History, Construction, and Social Influences, Ingram, Cooke, 1852. 